IZA DP No. 6070

Differentiation and Performance: An Empirical Investigation on the Incentive Effects of Bonus Plans

Patrick Kampkötter

Dirk Sliwka

October 2011 


\title{
Differentiation and Performance: An Empirical Investigation on the Incentive Effects of Bonus Plans
}

\author{
Patrick Kampkötter \\ University of Cologne \\ Dirk Sliwka \\ University of Cologne \\ and IZA
}

\section{Discussion Paper No. 6070 \\ October 2011}

\author{
IZA \\ P.O. Box 7240 \\ 53072 Bonn \\ Germany \\ Phone: +49-228-3894-0 \\ Fax: +49-228-3894-180 \\ E-mail: iza@iza.org
}

\begin{abstract}
Any opinions expressed here are those of the author(s) and not those of IZA. Research published in this series may include views on policy, but the institute itself takes no institutional policy positions.

The Institute for the Study of Labor (IZA) in Bonn is a local and virtual international research center and a place of communication between science, politics and business. IZA is an independent nonprofit organization supported by Deutsche Post Foundation. The center is associated with the University of Bonn and offers a stimulating research environment through its international network, workshops and conferences, data service, project support, research visits and doctoral program. IZA engages in (i) original and internationally competitive research in all fields of labor economics, (ii) development of policy concepts, and (iii) dissemination of research results and concepts to the interested public.
\end{abstract}

IZA Discussion Papers often represent preliminary work and are circulated to encourage discussion. Citation of such a paper should account for its provisional character. A revised version may be available directly from the author. 
IZA Discussion Paper No. 6070

October 2011

\begin{abstract}
Differentiation and Performance: An Empirical Investigation on the Incentive Effects of Bonus Plans

It is often claimed that supervisors do not differentiate enough between high and low performing employees when evaluating performance. The purpose of this paper is to study the incentive effects of this behavior empirically. We first show in a simple model that the perceived degree of past differentiation affects future incentives. We then study the impact of differentiation empirically with a large panel data set spanning many firms in one industry. On average, stronger differentiation has a substantial positive effect on performance. This effect is larger on higher hierarchical levels. But differentiation may become harmful at the lowest levels.
\end{abstract}

JEL Classification: M52, D23

Keywords: bonus payments, differentiation, subjective performance evaluation, incentives

Corresponding author:

Dirk Sliwka

University of Cologne

Albertus-Magnus-Platz

50923 Köln

Germany

E-mail: dirk.sliwka@uni-koeln.de 


\section{Introduction}

Most bonus contracts for employees in practice are not based on objective measures of performance but rather on a subjective performance assessment by a supervisor. But it has often been stressed (compare e.g. Prendergast and Topel (1996), Murphy and Cleveland (1995)) that supervisors tend to give performance ratings that are too compressed relative to the true performance of their employees. In that case bonus payments presumably will not reward high performance or sanction low performance adequately. A straightforward conjecture is that this should lead to lower levels of performance incentives.

In this paper we investigate this conjecture and in particular study the impact of differentiation in bonus payments on subsequent performance empirically. The research question we address is to what extent and under which organizational circumstances differentiation in bonus payments indeed affects future performance.

This question is of substantial practical relevance as many firms still struggle with the question on whether to enforce more differentiation. As for instance Jack Welch, who has put a large emphasis on establishing a culture of differentiation as CEO of General Electric, put it "Differentiation comes down to sorting out the A, B, and C players. [..]" (Welch (2003), pp. 195). He also admits "Differentiation isn't easy" (p. 153) and "[..] we spent over a decade building a performance culture with candid feedback at every level" (p. 199). And indeed there is an ongoing discussion on whether it is beneficial or harmful when differentiation is enforced. ${ }^{1}$ In a recent survey among employees from a broad set of firms only $41 \%$ of the respondents agree that supervisors differentiate enough between low and high performers. ${ }^{2}$

To study this question we use a large panel data set spanning many

\footnotetext{
${ }^{1}$ For discussions on the controversial issues in the popular press see for instance "Performance Reviews: Many Neeed Improvement" in the New York Times, September 10, 2006 or "The Struggle to Measure Performance" in Business Week, January 9, 2006.

${ }^{2}$ See Towers Watson Global Workforce Study 2010.
} 
different firms in one industry - namely the majority of larger banks in Germany - in which we can track individual bonus payments over time and have detailed information on specific functions and hierarchical levels. The key idea of our approach is the following: We investigate to what extent a higher variation in bonpayments in a certain unit and a given year leads to a higher performance in this unit in the subsequent year. Of course, unobserved individual heterogeneity will be an important issue as differentiation will also be driven by the specific amount of heterogeneity in abilities in the different units. We thus construct a balanced panel data set and make use of the within-department variation in the degree of differentiation to identify its effects on subsequent performance.

We illustrate the connection between past degrees of differentiation and future performance by first analyzing a simple model of subjective performance evaluations in which employees are uncertain about the precision with which their performance can be assessed but learn from past bonuses about the accuracy of the appraisal process. Supervisors who can accurately assess employee performance differentiate more in their ratings while those with a less accurate signal stay closer to prior performance expectations. In turn, bonus payments which deviate from the mean indicate that a supervisor is able to differentiate and this induces higher-powered incentives in the future. On the other hand, low degrees of differentiation lead to lower performance incentives as the employees' expected marginal return to effort is reduced.

While this reasoning indicates a positive connection between differentiation and performance, it is sometimes claimed in the management literature that differentiated ratings may destroy employee motivation (compare for instance the discussion in Pfeffer and Sutton (2006), pp. 125). From a behavioral economics perspective, fairness considerations may also play a role, as differentiation naturally leads to an unequal treatment of employees. If employees perceive a wage or bonus payment as unfair they may be tempted to decrease effort (see e.g. Akerlof and Yellen (1990), Fehr et al. (1993), 
Fehr et al. (1997), Ockenfels et al. (2010)). ${ }^{3}$ A further potential drawback of differentiation is that intra-firm competition for wages or bonus payments may undermine cooperation and lead to sabotage efforts that negatively affect firm performance (Lazear (1989)). ${ }^{4}$ Hence, the question which of these effects will dominate in practice is basically an empirical one. However, there is surprisingly little empirical evidence across a larger number of firms and different job types on this issue so far. ${ }^{5}$

Our key results are the following. We find that differentiation on average has a substantial and highly significant positive effect on individual performance. The effect is also of economic significance: When ranking units by their degree of differentiation we estimate that moving from the lowest to the highest quintile of differentiation future bonuses increase by $31 \%$ to $36 \%$. We also analyze whether the influence of differentiation on individual performance differs between hierarchical levels and functional areas. We find very strong positive effects of differentiation at the highest and intermediate levels. But surprisingly, we find a strongly reduced or even reversed effect of differentiation at the lowest hierarchical levels. Additionally, differentiation has the strongest effect in retail banking, where objective measures of performance are widely available and it has a much stronger effect on performance for managers as compared to experts.

There are so far many studies in which the relationship between differ-

\footnotetext{
${ }^{3}$ However, Abeler et al. (2010) find in a laboratory experiment that agents who receive the same wage exert significantly lower levels of effort than those who are paid according to individual performance. A key explanation is that undifferentiated wages can also be viewed as unfair when some workers have put in higher efforts than others.

${ }^{4}$ An intriguing novel rationalization for the claim that differentiation may undermine motivation has been recently given by Crutzen et al. (2010), who analyze a model in which a supervisor who is better informed about his subordinates' talent can increase the subordinates' self-image und thus their average efforts by refraining from differentiation.

${ }^{5}$ See for instance Rynes et al. (2005) who claim that "although there is a voluminous psychological literature on performance evaluation, surprisingly little of this research examines the consequences of linking pay to evaluated performance in work settings" (p. $572)$.
} 
entiation in fixed wages and firm performance ${ }^{6}$ or individual productivity $^{7}$ is studied empirically. But these studies report very mixed results. While tournament theory (e.g. Lazear and Rosen (1981)) indeed argues that a higher differentiation in agents' income should increase individual performance incentives, the actual differentiation in fixed wages in firms is also driven by many other considerations such as external market conditions, scarcity of specific talents, seniority wages, or cohort effects and may only indirectly affect the performance incentives. Only recently researchers have started to study the connection between differentiation in bonuses and performance. Bol (2011), for instance, uses two years of performance data on 200 employees in a Dutch financial services company and finds that rating compression is negatively correlated with subsequent subjective and objective performance measures. Engellandt and Riphahn (2011) use three years of panel data from a Swiss unit of an international company and detect a positive effect of a higher variability in ratings on future overtime work.

Finally, as rating differentiation determines the effective power of incentive schemes, our study also adds to the still rather scarce empirical literature investigating the effects of incentive schemes on productivity (for instance Lazear (2000), Knez and Simester (2001), Bandiera et al. (2007), Hossain and List (2009)).

The paper proceeds as follows. In section 2, the illustrative model is introduced. Section 3 provides an overview on the data set and the empirical strategy is described in detail. Sections 4 and 5 then investigate the performance effects of bonus dispersion for the whole data set as well as for separate subsamples. In section 6, robustness checks and extensions are presented. Finally, section 7 concludes.

\footnotetext{
${ }^{6}$ See e.g. Leonard (1990), Main et al. (1993), Eriksson (1999), Winter-Ebmer and Zweimüller (1999), Heyman (2005), Jirjahn and Kraft (2007), Grund and WestergaardNielsen (2008), or Martins (2008).

${ }^{7}$ See e.g. Becker and Huselid (1992), Pfeffer and Langton (1993), Drago and Garvey (1998), Bloom (1999), Depken II (2000), and Bloom and Michel (2002).
} 


\section{An Illustrative Model}

To illustrate how past differentiation affects incentives to exert effort we consider a simple model building on a framework used for instance by Prendergast and Topel (1996) or Prendergast (2002). Consider the situation of a risk neutral agent with initially unknown ability $a \sim N\left(m, \sigma_{a}^{2}\right)$ who works for two consecutive periods $t=1,2$. In each period he exerts effort $e_{t}$ at cost $c\left(e_{t}\right)$ and generates a performance outcome $y_{t}=e_{t}+a$. This performance is assessed by a supervisor who observes a noisy signal

$$
s_{t}=y_{t}+\eta_{t}
$$

with $\eta_{t} \sim N\left(0, \sigma_{\eta_{\theta}}^{2}\right)$. The supervisor now has either a high or a low ability in evaluating performance accurately, i.e. his type $\theta \in\{L, H\}$ with $\sigma_{\eta_{H}}^{2}<\sigma_{\eta_{L}}^{2}$ and $\operatorname{Pr}(\theta=H)=\tau$. The supervisor knows his type but the agent does not. In each period the supervisor observes $s_{t}$ and then reports a performance rating $r_{t}$. The agent receives a wage which is linear in $r_{t}$ such that

$$
w_{t}=\alpha+\beta \cdot r_{t}
$$

The supervisor herself has a preference to report the performance as accurately as possible. Her expected utility is ${ }^{8}$

$$
-E\left[\nu \cdot\left(\left(r_{t}-y_{t}\right)^{2}\right) \mid I_{t}\right]
$$

conditional on the information available in period $t$. This assumption guarantees that the supervisor reports his best estimate of the agent's performance.

Let $\hat{m}_{t}$ be the updated expectation of the agent's ability and $\hat{\sigma}_{a t}^{2}$ its vari-

\footnotetext{
${ }^{8}$ If the supervisor is completely selfish, a different interpretation is that the principal can verify the report with a certain probability and then imposes a fine $\left(r_{t}-y_{t}\right)^{2}$.
} 
ance at the beginning of period $t$. The supervisor solves

$$
\min _{r_{t}} p \cdot E\left[\nu \cdot\left(\left(r_{t}-y_{t}\right)^{2}\right) \mid s_{t}\right]
$$

This boils down to computing the least squares estimator of $y_{t}$ based on $s_{t}$ conditional on prior distributions which is equal to $E_{t}\left[y_{t} \mid s_{t}\right]$. Hence, the report is given by

$$
r_{t}\left(s_{t}, \sigma_{\eta_{\theta}}^{2}\right)=\left(1-\frac{\hat{\sigma}_{a t}^{2}}{\hat{\sigma}_{a t}^{2}+\sigma_{\eta_{\theta}}^{2}}\right)\left(\hat{m}_{t}+e_{t}^{*}\right)+\frac{\hat{\sigma}_{a t}^{2}}{\hat{\sigma}_{a t}^{2}+\sigma_{\eta_{\theta}}^{2}} s_{t} .
$$

First, note that

$$
V\left[r_{t}\right]=V\left[\frac{\hat{\sigma}_{a t}^{2}}{\hat{\sigma}_{a t}^{2}+\sigma_{\eta_{\theta}}^{2}} s_{t}\right]=\frac{\hat{\sigma}_{a t}^{4}}{\hat{\sigma}_{a t}^{2}+\sigma_{\eta_{\theta}}^{2}}
$$

is strictly decreasing in $\sigma_{\eta_{\theta}}^{2}$. Hence, a higher variance in the signal observed by the supervisor leads to a lower variance in reported performance. The reason is that a rater who can trust less in the accuracy of his own signal puts less emphasis on this observed signal when assessing the agent's performance. In turn we have a stronger 'distortion' towards the mean. Rating compression is therefore stronger when there is a lower accuracy in the appraisal process. Note that inaccurate signals thus lead to the so-called "centrality bias" in subjective performance evaluations.

But how does this affect the exerted efforts? To see that just consider the agent's optimization problem in period 2. The agent has observed his own first period appraisal and updated his belief on the accuracy of the appraisal process. Now denote the subjective probability that the appraisal is of high quality as $\hat{\tau}_{2}=\operatorname{Pr}\left(\theta=H \mid r_{1}\right)$. Using the supervisor's optimal report (1) we obtain the agent's expected utility

$$
\alpha+\beta\left(\hat{m}_{2}+e_{2}^{*}+\left(\hat{\tau}_{2} \frac{\hat{\sigma}_{a 2}^{2}}{\hat{\sigma}_{a 2}^{2}+\sigma_{\eta H}^{2}}+\left(1-\hat{\tau}_{2}\right) \frac{\hat{\sigma}_{a 2}^{2}}{\hat{\sigma}_{a 2}^{2}+\sigma_{\eta L}^{2}}\right)\left(e_{2}-e_{2}^{*}\right)\right)-c\left(e_{2}\right) .
$$


From the first-oder condition we get that

$$
e_{2}=c^{-1}\left(\beta\left(\hat{\tau}_{2} \frac{\hat{\sigma}_{a 2}^{2}}{\hat{\sigma}_{a 2}^{2}+\sigma_{\eta H}^{2}}+\left(1-\hat{\tau}_{2}\right) \frac{\hat{\sigma}_{a 2}^{2}}{\hat{\sigma}_{a 2}^{2}+\sigma_{\eta L}^{2}}\right)\right) .
$$

As $\frac{\partial e_{2}}{\partial \hat{\tau}_{2}}>0$ it directly follows that the agent's effort is upward sloping in the subjective belief about the quality of the appraisal process.

Finally, we can compute $\hat{\tau}_{2}=\frac{f\left(r_{1}, \theta=H\right)}{f\left(r_{1}\right)}$. Using that the first period report is normally distributed with a mean $m+e_{1}^{*}$ and variance $\frac{\sigma_{a}^{4}}{\sigma_{a}^{2}+\sigma_{\eta_{\theta}}^{2}}$ the conditional density of the first period report is

$$
f\left(r_{1} \mid \theta\right)=\frac{\sigma_{a}^{2}+\sigma_{\eta_{\theta}}^{2}}{\sigma_{a}^{4}} \phi\left(\left(\sigma_{a}^{2}+\sigma_{\eta_{\theta}}^{2}\right) \frac{r_{1}-m-e_{1}^{*}}{\sigma_{a}^{4}}\right)
$$

where $\phi($.$) is the density of the standard normal distribution. Hence,$

$$
\hat{\tau}_{2}=\frac{\tau \frac{\sigma_{a}^{2}+\sigma_{\eta_{H}}^{2}}{\sigma_{\varepsilon}^{4}} \phi\left(\left(\sigma_{a}^{2}+\sigma_{\eta_{H}}^{2}\right) \frac{r_{1}-m-e_{1}^{*}}{\sigma_{\varepsilon}^{4}}\right)}{\tau \frac{\sigma_{a}^{2}+\sigma_{\eta_{H}}^{2}}{\sigma_{\varepsilon}^{4}} \phi\left(\left(\sigma_{a}^{2}+\sigma_{\eta_{H}}^{2}\right) \frac{r_{1}-m-e_{1}^{*}}{\sigma_{\varepsilon}^{4}}\right)+(1-\tau) \frac{\sigma_{a}^{2}+\sigma_{\eta}^{2}}{\sigma_{a}^{4}} \phi\left(\left(\sigma_{a}^{2}+\sigma_{\eta_{L}}^{2}\right) \frac{r_{1}-m-e_{1}^{*}}{\sigma_{a}^{4}}\right)} .
$$

If we now substitute $x=r_{1}-m-e_{1}^{*}$ it is straightforward to see that this expression is symmetric in $x$. Furthermore, it has a unique global minimum at $x=0$ and $\lim _{x \rightarrow+\infty} \hat{\tau}_{2}=\lim _{x \rightarrow-\infty} \hat{\tau}_{2}=1$. The function is thus U-shaped in the deviation from the mean of potential evaluations (see figure 1). We therefore obtain:

Proposition 1 A higher variance of first period ratings leads to a stronger belief in a performance-contingent appraisal process and in turn to higher second period efforts.

Hence, agents learn from past degrees of differentiation on future differentiation and this directly affects their incentives to exert effort. 


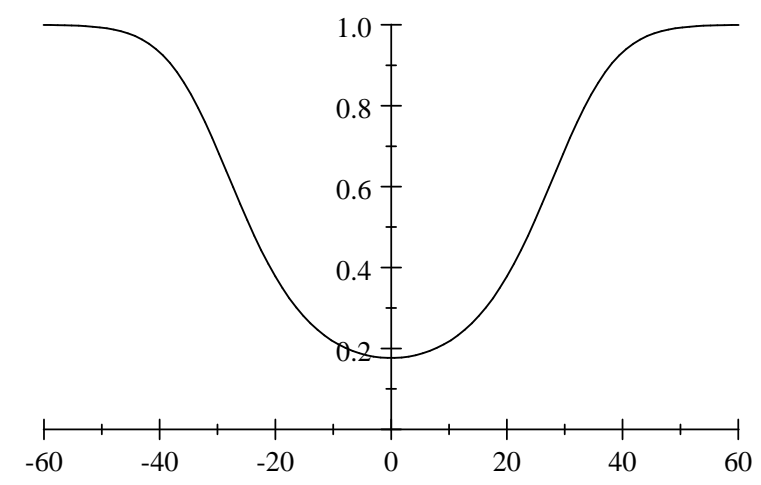

Figure 1: Probability that $\theta=H$ as a function of $r_{1}-m-e_{1}^{*}$

\section{The Data}

We now investigate the connection between past differentiation and future performance using a panel data set on compensation in the German banking and financial services sector for the years 2005-2007. The data set is owned by the management consultancy Towers Watson and is used for professional compensation benchmarking. ${ }^{9}$ It covers all the largest German banks and financial services companies and contains detailed individual information on base salary, bonus payments, age, firm tenure, hierarchical level (6 levels), functional area, and specific function. Descriptive statistics are provided in table A2 in the appendix. ${ }^{10}$

The functional areas represent a broad classification of the main sectors in the banking and financial services industry: Retail banking (RB), asset management $(\mathrm{AM})$, corporate banking $(\mathrm{CB})$ and private banking $(\mathrm{PB})$, investment banking (IB), treasury and capital markets (TCM), the typically lower-skilled service functions (corporate services (CS)) as well as the crossdivisional functions (corporate production (CP)). Most of the employees in

\footnotetext{
${ }^{9}$ Towers Watson (formerly Towers Perrin) data sets have in economics, for instance, also been used by Abowd and Kaplan (1999), Murphy (1999), and Murphy (2001).

${ }^{10}$ Due to confidentiality reasons, company names had to be anonymized.
} 
the data set are working in retail banking and in the service and corporate functions, followed by corporate banking. But we make also use of a much more detailed classification of industry-specific jobs, as these functional areas are subdivided into about 60 specific functions. ${ }^{11}$ The distribution of employee-year observations by hierarchical level is shown in table 1.

\begin{tabular}{l|c|c}
\hline \hline Level & \multicolumn{2}{|c}{ Balanced panel $2005 / 07$} \\
& Frequency & Percent \\
\hline 6 (highest) & 514 & 1.18 \\
5 & 6,007 & 13.78 \\
4 & 11,150 & 25.58 \\
3 & 11,275 & 25.86 \\
2 & 12,619 & 28.95 \\
1 (lowest) & 2,029 & 4.65 \\
\hline Total & 43,594 & 100.00 \\
\hline \hline
\end{tabular}

Table 1: Distribution by hierarchical level

A very useful feature of this data set is the systematic comparability of employee positions across different firms. As the consultancy offers compensation benchmarking services, it applies a standardized job evaluation method to determine the specific function and hierarchical level of a job. Therefore so-called career levels are defined that reflect typical steps in an individual's career. Each career level is described through detailed profiles of the skills, knowledge and behaviors that are required for the position. These levels are then integrated into four career ladders for managerial positions on the one hand and functional experts on the other (i.e. professional, sales and support). In our sample, about $48 \%$ of all employee-year observations belong to the sales ladder, more than $20 \%$ to the professional ladder and about $10 \%$ are managerial positions.

The empirical strategy is as follows. We analyze a balanced panel data set to investigate the effects of differentiation within a department on indi-

\footnotetext{
${ }^{11} \mathrm{~A}$ list of exemplary functions is given in table A1 in the appendix.
} 
vidual performance in the subsequent year. In a first step, we generate cells capturing the organizational units of a company. A unit is characterized by a unique combination of year, company, functional area, detailed function, career ladder and hierarchical level. We restrict our analysis to cells with a minimum number of three observations. Then we compute different measures of bonus dispersion within each unit and for each year: the coefficient of variation, i.e. the ratio of the standard deviation to the mean, the P90/P10 ratio, i.e. the ratio of the 90th to the 10th percentile and the standard deviation of logs. We include only observations with non-missing and positive actual bonus payments to capture only positions which are eligible for a bonus payment.

It is important to understand why we use the bonus as key dependent variable. The prevalent structure of a bonus plan in a bank is the following: Typically, a so-called bonus pool is assigned to a unit and the size of the pool usually depends on the overall company's and the unit's own financial performance. This bonus pool is then distributed across the subunits and finally across individual employees in the unit - typically based in the end on a subjective assessment of the employees' performance. Hence, the bonus payment is a direct function of a unit's financial success and the individual employee's contribution to this success. Higher bonuses can only be achieved with a higher financial and individual performance. Indeed, a recent survey by Towers Watson among the banks in the studied data set shows that $78 \%$ of the respondents use such a bonus pool system and in most of the remaining companies individual bonuses depend on the financial performance of the bank and the relevant subunit in some other form. We will show in section 6 that within-bank variations of financial success over time indeed strongly predict variations in the actual bonus payments. Hence, bonuses are a very useful measure of an individual employees' profit contribution. Moreover, bonus payments can be compared across and within departments in the different banks considered. It is virtually impossible to find another measure 
of individual performance that is comparable across such broad categories of employees.

We follow a conservative approach by restricting all samples to employees staying at the same hierarchical level, specific function and career ladder throughout all the years. Hence, we drop a large number of employees to obtain a balanced panel data set. This is important to exclude variability in bonus payments due to employee movements like promotions, functional rotation, entry, exit or changes in team composition. ${ }^{12}$ In the 2005-2007 panel, about 12,000 individuals can be observed over a three-year period with 1,455 unique cell-year combinations and an average (median) size of 31 (7) observations per cell.

We then run regressions with employee fixed effects where the log of the individual bonus payment of a person $i$ in a year $t$ is the dependent variable. Our key independent variable is the measure of dispersion (coefficient of variation, $\mathrm{P} 90 / \mathrm{P} 10$ ratio, and standard deviation of logs) of bonus payments in year $t-1$ in the relevant cell. Additional control variables include the log of base salary, age, firm tenure, functional area, function, career ladder, company and year. In the baseline regressions, we use two specifications to analyze the effects of differentiation: In the first specification, the dispersion measures are included as independent variables in the regression models. To allow for nonlinear effects of differentiation and to quantify economic significance, these measures are further categorized into quintiles and we include dummy variables for each quintile.

\footnotetext{
${ }^{12}$ All key results remain stable when we use the larger unbalanced data set.
} 


\section{Performance Effects of Differentiation}

\subsection{How much Differentiation?}

There is substantial variation in the degree of differentiation between the organizational units. Descriptive statistics of the dispersion measures for the balanced panel are shown in table 2 .

\begin{tabular}{l|c|c|c|c|c}
\hline \hline Level & \multicolumn{5}{|c}{ Balanced panel 2005/07 } \\
& Mean & Median & SD & Min & Max \\
\hline CV & 0.33 & 0.27 & 0.20 & 0 & 2.06 \\
P90/P10 & 2.59 & 1.93 & 2.76 & 1 & 77.28 \\
SD of logs & 0.33 & 0.29 & 0.18 & 0 & 1.90 \\
\hline \hline
\end{tabular}

Table 2: Descriptive statistics for measures of dispersion

The lowest coefficient of variation, for example, is 0 and the highest 2.06, with a mean value of 0.33 (median 0.27). Regarding the P90/P10 ratio, we obtain values between 1 and 77.28 with a mean ratio of 2.59 and a median of 1.93. The deciles of the coefficient of variation are displayed in figure $2 .{ }^{13}$

Table A3 in the appendix reports median values of the coefficient of variation and the P90/P10 ratio in bonus payments for the years 2005 to 2007 by hierarchical level. There is a slight tendency that the degree of variation increases with the hierarchical level. It is interesting to note that there are also differences in the degree of variation between the broader functional areas as reported in table A4 in the appendix. ${ }^{14}$ The highest rates of variation in bonus payments can be found in the capital market-based functions treasury and capital markets, investment banking and asset management. These areas are also characterized by very high absolute bonus payments. In retail banking, however, we observe the lowest levels of differentiation.

\footnotetext{
${ }^{13}$ Figure 3 in the appendix shows the deciles of the $\mathrm{P} 90 / \mathrm{P} 10$ ratio.

${ }^{14}$ Due to a small number of observations, the functional areas investment banking, asset management, and treasury and capital markets are pooled.
} 


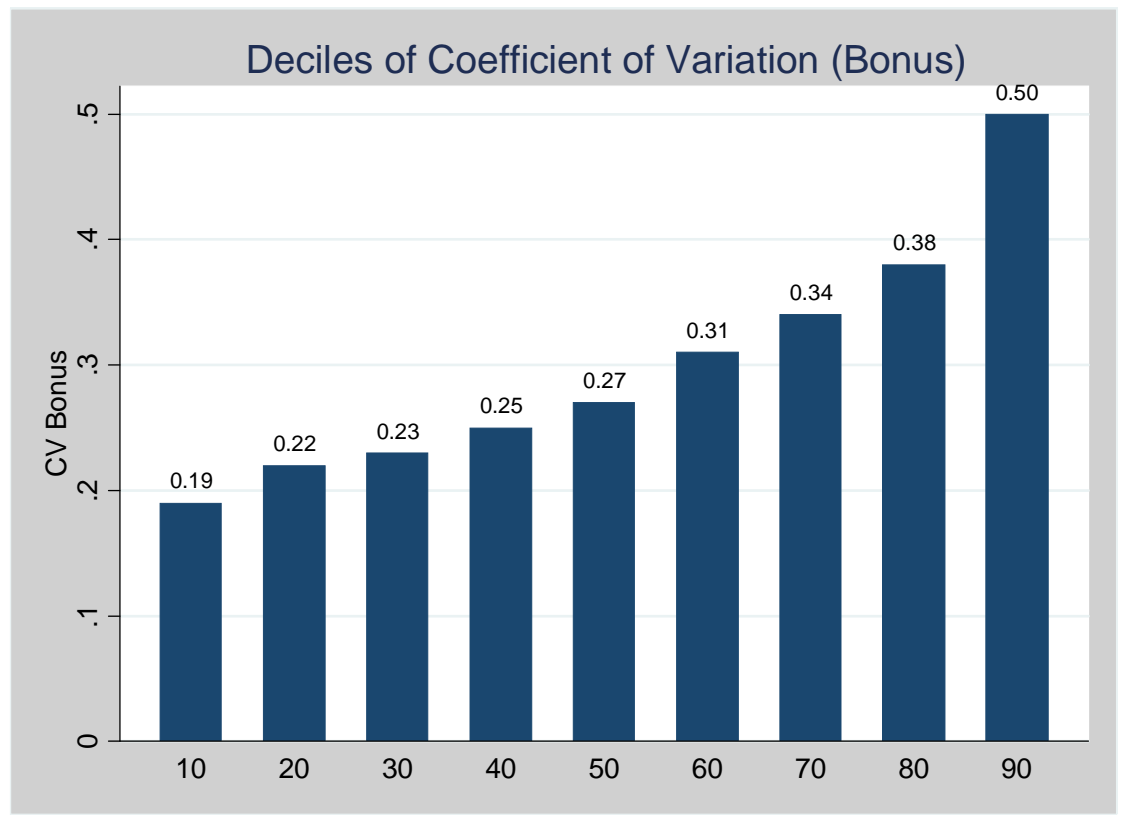

Figure 2: Deciles of coefficient of variation for bonus payments

But we also find large differences in the coefficient of variation even within the more detailed specific functions. The coefficient of variation in Human Resources, for example, ranges from 0 to 1.40, in Marketing from 0.01 to 0.76, in Sales Assistance from 0.02 to 0.92, in Corporate Finance from 0.65 to 0.86 , and in IT Generalist functions from 0.03 to 0.44 . Similar differences can be found for the other dispersion measures. But it is important to note that we do not use this between-department differences for our empirical analysis but the variation in the degree of differentiation within departments over time.

\subsection{Differentiation and Performance}

Table 3 reports estimation results of the baseline regressions with individual fixed effects and the logarithm of bonus payments as dependent variable 
using the balanced panel data set for the years 2005-2007. Key independent variable is the respective measure of dispersion for the relevant cell in the previous year. To account for potential within-cell correlation in the error terms we report robust standard errors clustered on cell-level. All models include the time varying logarithm of base salary, age, firm tenure, and year as further control variables. Recall that our panel includes only employees that did not change the employer, hierarchical level, functional area, function and career ladder throughout the whole period 2005-2007.

The results in table 3 show that there is a highly significant positive relationship between differentiation and future performance, i.e. an increase in the degree of differentiation in a departments' bonus payments in one year is associated with significantly higher individual bonus payments in the subsequent year for all three indicators. A one standard deviation increase in the coefficient of variation (P90/P10 ratio) leads to an increase in bonus payments of about $10 \%$ (7\%), all other factors constant. To give some further indication about the economic significance of this effect, we ranked all cells by the degree of differentiation and then created dummy variables for each quintile in the distribution of the measures of dispersion. The coefficient for the 5th quintile now gives an estimate of the percentage change in performance when a supervisor who is among the $20 \%$ of weakest differentiators moves to the degree of differentiation applied by the $20 \%$ strongest differentiators. Note that these effects are quite sizeable. For the coefficient of variation the model in table 3 predicts a $31 \%$ increase $^{15}$ in performance when moving from rather undifferentiated incentives to highly differentiated bonus payments. The coefficients for the P90/P10 ratio and the standard deviation of logs are even slightly higher with a predicted $33 \%$ respectively $36 \%$ increase in subsequent performance. It is interesting to note that the effects are roughly monotonic in all specifications, i.e. the effects increase when moving from the lowest quintile to the highest one.

\footnotetext{
${ }^{15}$ Note that $e^{0.2693}=1.31$. See e.g. Halvorsen and Palmquist (1980) for details.
} 


\begin{tabular}{|c|c|c|c|c|c|c|}
\hline \multirow[t]{2}{*}{ Dependent variable: } & \multicolumn{6}{|c|}{ Logarithm of bonus payments } \\
\hline & \multicolumn{2}{|c|}{ Coef. of variation } & $\mathrm{P} 90 / \mathrm{P}$ & 0 ratio & Std. de & of $\log s$ \\
\hline \multirow[t]{2}{*}{ Differentiation $_{t-1}$} & $0.5026^{* *}$ & & $0.0238^{* * *}$ & & $0.6575^{* * *}$ & \\
\hline & $(0.2168)$ & & $(0.0092)$ & & $(0.2008)$ & \\
\hline \multirow[t]{2}{*}{$2^{n d}$ Quintile $_{t-1}$} & & $0.2044^{* * *}$ & & -0.0542 & & -0.0548 \\
\hline & & $(0.0691)$ & & $(0.0413)$ & & $(0.1443)$ \\
\hline \multirow[t]{2}{*}{$3^{r d}$ Quintile $_{t-1}$} & & $0.1547^{* *}$ & & 0.1935 & & 0.0564 \\
\hline & & $(0.0659)$ & & $(0.1265)$ & & $(0.0636)$ \\
\hline \multirow[t]{2}{*}{$4^{t h}$ Quintile $_{t-1}$} & & $0.2265^{* * *}$ & & $0.2519^{* *}$ & & $0.1673^{* *}$ \\
\hline & & $(0.0750)$ & & $(0.1198)$ & & $(0.0743)$ \\
\hline \multirow[t]{2}{*}{$5^{t h}$ Quintile $_{t-1}$} & & $0.268^{* * *}$ & & $0.2876^{* * *}$ & & $0.3080^{* * *}$ \\
\hline & & $(0.0958)$ & & $(0.1100)$ & & $(0.0902)$ \\
\hline \multirow[t]{2}{*}{ Ln Base salary $t_{t}$} & -0.4489 & -0.3372 & -0.3346 & -0.3671 & -0.3815 & $-0.6278^{* *}$ \\
\hline & $(0.3062)$ & $(0.3333)$ & $(0.2883)$ & $(0.2906)$ & $(0.2879)$ & $(0.2553)$ \\
\hline \multirow[t]{2}{*}{ Age squared $t$} & $0.0001^{* * *}$ & $0.0002^{* * *}$ & $0.0001^{* * *}$ & $0.0001^{* * *}$ & $0.0001^{* *}$ & $0.0170^{* * *}$ \\
\hline & $(0.00005)$ & $(0.00005)$ & $(0.00004)$ & $(0.0001)$ & $(0.00005)$ & $(0.0024)$ \\
\hline Observations & 25587 & 25587 & 25587 & 25587 & 25587 & 25587 \\
\hline $\mathrm{R}^{2}$ within & 0.09 & 0.06 & 0.08 & 0.08 & 0.09 & 0.08 \\
\hline 1 std. dev. increase & $10 \%$ & & $7 \%$ & & $12 \%$ & \\
\hline
\end{tabular}

Additional year dummies included. Robust standard errors clustered for cells in parentheses.

*** $\mathrm{p}<0.01,{ }^{*} * \mathrm{p}<0.05,{ }^{*} \mathrm{p}<0.1$

Table 3: Fixed effects regression results with measures of dispersion for balanced panel 2005-2007 


\section{Levels, Functional Areas, and Career Lad- ders}

It is important to investigate whether this effect also holds for different subgroups of employees as the effect of differentiation should depend on the type of job. In some areas it may be rather simple to give differentiated performance ratings, for instance, as objective measures of individual performance are widely available (such as financial performance indicators). But in other areas it is quite difficult to assess the individual performance of employees. In addition, differentiated ratings often directly lead to relative performance evaluation of employees. ${ }^{16}$ As has for instance been pointed out by Lazear (1989), this may even generate incentives to sabotage colleagues and reduce cooperation and teamwork. Hence, it is conceivable that differentiation may even be harmful in certain units.

\subsection{Hierarchical Levels}

We start by investigating the effects of the hierarchical level. To do this we first included interaction terms between the measures of differentiation and each of the six hierarchical levels in the baseline regression model. The reference category is level 1 , the lowest level in the data set.

These regressions yield some surprising results, as shown in table 4 . First of all, the effects of differentiation on subsequent bonus payments are increasing in the hierarchical level an employee is located at. From level 4 upwards, we find a highly significant positive relationship between differentiation and future performance.

But strikingly the effects are reversed at the lowest levels: stronger degrees of differentiation come along with a lower subsequent performance on level 1 and the effect is even significant for the P90/P10 ratio. As tables A5 and A6

\footnotetext{
${ }^{16}$ This is necessarily the case when the supervisors are forced to follow a given distribution of performance grades as employees then compete for the top grades.
} 


\begin{tabular}{|c|c|c|c|}
\hline \multirow[t]{2}{*}{ Dependent variable: } & \multicolumn{3}{|c|}{$\begin{array}{c}\text { Logarithm of bonus payments } \\
\text { Balanced panel } 2005-2007\end{array}$} \\
\hline & Coef. of variation & $\mathrm{P} 90 / \mathrm{P} 10$ ratio & Std. dev. of logs \\
\hline Differentiation $t-1$ & $\begin{array}{l}-0.3793 \\
(0.3234)\end{array}$ & $\begin{array}{c}-0.0222^{* *} \\
(0.0108)\end{array}$ & $\begin{array}{l}-0.1083 \\
(0.3185)\end{array}$ \\
\hline Differentiation $_{t-1} \times$ Level $2^{a}$ & $\begin{array}{l}-0.5199 \\
(0.4123)\end{array}$ & $\begin{array}{l}-0.0349 \\
(0.0565)\end{array}$ & $\begin{array}{c}0.7703 \\
(1.0120)\end{array}$ \\
\hline Differentiation $_{t-1} \times$ Level 3 & $\begin{array}{c}0.2569 \\
(0.4757)\end{array}$ & $\begin{array}{l}0.0296^{*} \\
(0.0166)\end{array}$ & $\begin{array}{c}0.1734 \\
(0.3654)\end{array}$ \\
\hline Differentiation $_{t-1} \times$ Level 4 & $\begin{array}{c}1.1724^{* * *} \\
(0.3952)\end{array}$ & $\begin{array}{c}0.0427^{* * *} \\
(0.0152)\end{array}$ & $\begin{array}{l}0.9313^{* *} \\
(0.4498)\end{array}$ \\
\hline Differentiation $_{t-1} \times$ Level 5 & $\begin{array}{c}1.2041^{* * *} \\
(0.3665)\end{array}$ & $\begin{array}{c}0.0804^{* * *} \\
(0.0181)\end{array}$ & $\begin{array}{c}1.0419^{* *} \\
(0.5290)\end{array}$ \\
\hline Differentiation $_{t-1} \times$ Level 6 & $\begin{array}{c}2.2380^{* * *} \\
(0.7129)\end{array}$ & $\begin{array}{c}0.1213^{* * *} \\
(0.0242)\end{array}$ & $\begin{array}{c}1.6416^{* * *} \\
(0.5757)\end{array}$ \\
\hline Ln Base salary $t_{t}$ & $\begin{array}{l}-0.1678 \\
(0.2663)\end{array}$ & $\begin{array}{l}-0.2895 \\
(0.2777)\end{array}$ & $\begin{array}{l}-0.3403^{*} \\
(0.2014)\end{array}$ \\
\hline Observations & 25587 & 25587 & 25587 \\
\hline$R^{2}$ within & 0.15 & 0.10 & 0.11 \\
\hline
\end{tabular}

Table 4: Interactions between measures of dispersion and hierarchical levels 
in the appendix, which report separate regressions for subsamples containing only two adjacent hierarchical levels, show, this is particularly driven by a drop in performance for very high degrees of differentiation at the lowest hierarchical levels.

There are several potential explanations for this effect. First of all, at higher hierarchical levels supervisors can more often rely on financial indicators to assess the performance of employees while at lower levels financial performance is typically measured at the team level. Moreover, firms spend much more resources on collecting performance information about higher level managers than for lower level employees. ${ }^{17}$ For instance, when evaluating the performance of higher level managers many firms collect information from different sources, for instance in so-called $360^{\circ}$ feedback systems, where subordinates and colleagues give input about their peception of a manager's performance, or in management panels where several higher level managers jointly assess the performance of managers one level below. In the spirit of the model presented in section 2, the availability of objective measures of performance and the higher visibility of managers reduces the uncertainty in evaluating performance and therefore should lead to a higher accuracy and in turn to a higher variance in ratings. ${ }^{18}$ In the model lower values of $\sigma_{\eta_{\theta}}^{2}$ at the same time reduce the share of unwanted noise in the overall variance in ratings as given by (2) and increase equilibrium efforts (3). Hence, a lower uncertainty indeed should lead to a closer connection between variance in ratings and exerted efforts.

On the other hand, on lower levels firms typically rely on the subjective judgement of a single supervisor and as is well known from the empirical literature in personnel psychology, these subjective performance assessments are often affected by personal preferences of supervisors ${ }^{19}$. When this is

\footnotetext{
${ }^{17}$ A simple extension of the model rationalizes this behavior: For agents whose efforts are more valuable for the firm an investment in reducing assessment noise is more beneficial, and in turn firms should invest more to bring down $\sigma_{\eta_{\theta}}^{2}$.

${ }^{18}$ Indeed, ratings are more differentiated at higher levels as table A3 shows.

${ }^{19}$ See e.g. Murphy and Cleveland (1995) for an overview. Kane et al. (1995) for in-
} 
the case more differentiation can be harmful as it may come along with an unequal treatment of workers which is not due to different productivity levels. Furthermore, it is conceivable that social comparisons may play a bigger role at lower levels, in particular, when ratings are mostly subjective. Indeed there is now some evidence that unwanted social comparisons may be detrimental for employee satisfaction and performance (see e.g. Card et al. (2010), Ockenfels et al. (2010)).

Finally, employees within a certain unit typically work closely together at lower levels in the hierarchy. Strong differentiation may then cause withinteam competition and therefore can have detrimental effects when cooperation is very important. But managers at higher levels lead separate teams of lower-level employees and such detrimental effects of differentiation should be less severe. Berger et al. (2010), for instance, investigate the performance impact of exogenously forced differentiation in bonus payments in a lab experiment and find that while enforcing differentiation is beneficial when there is no interaction among the members of a work group, it is highly detrimental when workers have an opportunity to harm each other.

\subsection{Functional Areas}

Given the sizeable differences in the effects at the various hierarchical levels we should also expect differences between the functional areas. Recall that most of the employees in our data set are working in retail banking. This area is characterized by a high level of standardized sales and back office activities. Hence, objective measures of individual performance are more readily available making differentiated ratings easier. Furthermore, the structure of the units we consider in retail banking is different as we observe cells in this

stance show that there are substantial differences between the ratings given by different supervisors to the same employees. For a discussion from an economic perspective see for instance Prendergast and Topel (1996) or Prendergast (2002). 
area comprising a large number of employees. ${ }^{20}$

To test whether the aggregate results are driven by certain characteristics of the retail banking area, we reran the baseline regressions for a subsample where retail banking is excluded. As table 5 shows the results even get stronger.

\begin{tabular}{|c|c|c|c|c|c|c|}
\hline \multirow[t]{3}{*}{ Dependent variable: } & \multicolumn{6}{|c|}{ Logarithm of bonus payments } \\
\hline & \multicolumn{6}{|c|}{ Balanced panel 2005-2007 (retail banking excluded) } \\
\hline & \multicolumn{2}{|c|}{ Coef. of variation } & \multicolumn{2}{|c|}{$\mathrm{P} 90 / \mathrm{P} 10$ ratio } & \multicolumn{2}{|c|}{ Std. dev. of logs } \\
\hline \multirow[t]{2}{*}{ Differentiation $_{t-1}$} & $0.3837^{* *}$ & & $0.0191^{* *}$ & & $0.5851^{* * *}$ & \\
\hline & $(0.1891)$ & & $(0.0075)$ & & $(0.1661)$ & \\
\hline \multirow[t]{2}{*}{$2^{n d}$ Quintile $_{t-1}$} & & $0.1841^{* *}$ & & 0.0916 & & -0.0911 \\
\hline & & $(0.0924)$ & & $(0.1134)$ & & $(0.1374)$ \\
\hline \multirow[t]{2}{*}{$3^{r d}$ Quintile $_{t-1}$} & & $0.2338^{* * *}$ & & $0.2868^{* *}$ & & $0.1700^{*}$ \\
\hline & & $(0.0838)$ & & $(0.1168)$ & & $(0.0904)$ \\
\hline \multirow[t]{2}{*}{$4^{\text {th }}$ Quintile $_{t-1}$} & & $0.2190^{* * *}$ & & $0.2997^{* *}$ & & $0.2581^{* * *}$ \\
\hline & & $(0.0788)$ & & $(0.1219)$ & & $(0.0938)$ \\
\hline \multirow[t]{2}{*}{$5^{t h}$ Quintile $_{t-1}$} & & $0.2736^{* * *}$ & & $0.4214^{* * *}$ & & $0.3684^{* * *}$ \\
\hline & & $(0.0809)$ & & $(0.1007)$ & & $(0.1007)$ \\
\hline \multirow[t]{2}{*}{ Ln Base salary $t$} & -0.4957 & -0.3641 & -0.4106 & $-0.5732^{*}$ & -0.3629 & $-0.6797^{* *}$ \\
\hline & $(0.4074)$ & $(0.3953)$ & $(0.3891)$ & $(0.3051)$ & $(0.3948)$ & $(0.2717)$ \\
\hline \multirow[t]{2}{*}{ Age squared $t$} & 0.0012 & 0.0017 & 0.0014 & 0.0007 & 0.0007 & 0.0008 \\
\hline & $(0.0013)$ & $(0.0015)$ & $(0.0014)$ & $(0.0011)$ & $(0.0012)$ & $(0.0011)$ \\
\hline Observations & 11343 & 11343 & 11343 & 11343 & 11343 & 11343 \\
\hline $\mathrm{R}^{2}$ within & 0.12 & 0.10 & 0.11 & 0.15 & 0.13 & 0.14 \\
\hline 1 std. dev. increase & $10 \%$ & & $8 \%$ & & $14 \%$ & \\
\hline
\end{tabular}

Additional year dummies included. Robust standard errors clustered for cells in parentheses.

$* * * \mathrm{p}<0.01,{ }^{* *} \mathrm{p}<0.05, * \mathrm{p}<0.1$

Table 5: Fixed effects regression results with measures of dispersion (retail banking excluded)

In a second step we estimate the performance effects of differentiation for subsamples comprising different functional areas. Besides retail banking, we

\footnotetext{
${ }^{20}$ The average cell size is 230 observations compared to 15 observations for all other areas excluding retail banking.
} 
consider the following broader areas: Corporate and private banking cover banking services for corporations and wealthy private clients. Corporate services comprise lower-skilled customer support and administration jobs like secretaries, call center agents, facility managers, and reception desks. Corporate production contains typical (cross-divisional) support functions such as human resources, finance, accounting, marketing, legal, and economics. Furthermore we look at the subsample comprising the capital market-based functions investment banking, asset management and treasury and capital markets which cover jobs e.g. in money markets, corporate finance, and fund management. Given our previous considerations we expect that differentiation is beneficial in most areas but may be less effective or even harmful in corporate services where there are many lower-level jobs and corporate production where individual performance is typically hard to assess objectively and bonus payments have to rely on subjective and therefore typically less accurate evaluations.

As table 6 shows there are indeed substantial differences among the functional areas. Differentiation has the strongest effect in private and corporate banking and retail banking, with a one standard deviation increase in differentiation levels leading to about $20 \%$ higher bonus payments. This may not be surprising as these are areas with direct sales activities and objective measures of performance are more readily available making it easier to assign differentiated ratings. ${ }^{21}$

It is further quite interesting that the effects are positive and sizeable in corporate production where we had expected weaker effects. We also find a positive and significant relationship between differentiation and performance in investment banking, asset management and treasury and capital markets. Note that, in line with the above reasoning, we observe a negative coefficient for corporate services.

\footnotetext{
${ }^{21}$ It is notable that average differentiation levels are rather low in retail banking (see Table A4). But this is mostly due to the fact that retail banking comprises a rather high share of lower-level jobs in which differentiation is weaker.
} 


\begin{tabular}{lccccc}
\hline \hline \multirow{2}{*}{ Dependent variable: } & \multicolumn{5}{c}{ Logarithm of bonus payments (Balanced panel 2005-2007) } \\
& $\mathrm{CP}$ & $\mathrm{CS}$ & $\mathrm{IB} / \mathrm{AM} / \mathrm{TCM}$ & $\mathrm{PB} / \mathrm{CB}$ & $\mathrm{RB}$ \\
\hline CV Bonus $_{t-1}$ & $0.5987^{* * *}$ & $-0.7285^{* *}$ & $0.5118^{*}$ & $0.6553^{* * *}$ & $1.8398^{* * *}$ \\
& $(0.2183)$ & $(0.3552)$ & $(0.2691)$ & $(0.1753)$ & $(0.6565)$ \\
Ln Base salary $t$ & $-0.5228^{*}$ & -0.2588 & -0.3534 & -0.2499 & -0.3251 \\
& $(0.2872)$ & $(0.6725)$ & $(0.2116)$ & $(0.2730)$ & $(0.4219)$ \\
Age squared & 0.0025 & 0.0015 & $-0.0034^{*}$ & -0.0024 & $0.0001^{* *}$ \\
& $(0.0024)$ & $(0.0013)$ & $(0.0018)$ & $(0.0031)$ & $(0.00004)$ \\
\hline Observations $^{2}$ within & 4041 & 5131 & 1002 & 1169 & 14244 \\
1 std. dev. increase $^{\text {stde }}$ & 0.21 & 0.10 & 0.21 & 0.28 & 0.17 \\
\hline \hline
\end{tabular}

Additional year dummies included. Robust standard errors clustered for cells in parentheses.

*** $\mathrm{p}<0.01,{ }^{* *} \mathrm{p}<0.05, * \mathrm{p}<0.1$

Table 6: Fixed effects regression results for subgroups of functional areas (coefficient of variation)

Further analyses show that the effect of differentiation also varies between hierarchical levels within the functional areas. While differentiation in the retail banking area is harmful at the lowest levels in the hierarchy, it has again a strong positive effect at intermediate levels.

\subsection{Managers or Professionals}

The argument that differentiation is more beneficial for jobs in which employees have stronger independent responsibilities can also be tested differently by making use of an additional feature of the data set: The jobs considered are separated into four different career ladders: one management ladder (leadership positions) and three expert/professional ladders (sales, support and professional). Each ladder spans different hierarchical levels. Note that there are experts also at higher hierarchical levels. These are typically employees with a high functional expertise but without general managerial responsibilities. Given the above explanation we expect that differentiation should have the strongest effect on performance in the managerial ladder as managerial 
jobs have stronger independent responsibilities and performance can be assessed more directly. To analyze these effects we include interaction terms between the different measures of dispersion and the career ladders into the baseline regression model.

This is indeed confirmed by the results reported in table 7, where the professional ladder has been chosen as reference group. Column 1 reports regressions results for all hierarchical levels in the data set. But as some of the career ladders do not span all levels, we also report results for the intermediate levels 3 and 4 , where jobs exist in all four career ladders.

\begin{tabular}{lccc}
\hline \hline Dependent variable: & \multicolumn{3}{c}{$\begin{array}{c}\text { Logarithm of bonus payments } \\
\text { Balanced panel 2005-2007 }\end{array}$} \\
& All levels & Level 3 & Level 4 \\
\hline CV Bonus $_{t-1}$ & $0.5339^{* * *}$ & $0.4922^{*}$ & $0.4003^{* * *}$ \\
& $(0.1002)$ & $(0.2580)$ & $(0.0773)$ \\
CV Bonus $_{t-1} \times$ Management $^{a}$ & $1.9993^{* * *}$ & $1.9007^{*}$ & $2.0968^{* * *}$ \\
& $(0.2352)$ & $(1.0026)$ & $(0.1991)$ \\
CV Bonus $_{t-1} \times$ Sales & -0.5917 & -1.5855 & $1.9634^{* * *}$ \\
& $(0.5915)$ & $(1.1328)$ & $(0.5796)$ \\
CV Bonus $_{t-1} \times$ Support & $-1.2789^{* * *}$ & $-0.9902^{* * *}$ & -0.1177 \\
& $(0.2761)$ & $(0.3522)$ & $(0.4312)$ \\
\hline Observations $_{R^{2}}$ within & 25587 & 6793 & 6362 \\
\hline \hline
\end{tabular}

Age squared, base salary and year dummies included. ${ }^{a}$ Reference cat.: career ladder professional.

Robust stand. errors clustered for cells in parentheses. *** $\mathrm{p}<0.01,{ }^{* *} \mathrm{p}<0.05,{ }^{*} \mathrm{p}<0.1$

Table 7: Interactions with career ladders (coefficient of variation)

Differentiation has, on average, a positive and significant effect for employees in the professional ladder. But the effect is much stronger for managerial employees, as the interaction term is very large. This result is robust in all specifications. The negative effect for employees in support functions is in line with the previous results on the different functions.

To study the effects of differentiation on performance within the main career ladders, we replicate the baseline model for a subsample of the two 
largest career ladders, the management and professional ladder. As can be seen in table A7 in the appendix, this yields some interesting results. In the management ladder, higher levels of differentiation come along with increasing positive performance effects. But for functional expert positions, the pattern is different. First, the coefficients are much smaller than in the regressions for management employees. And, more interestingly, for professional employees the interaction terms of the $3 \mathrm{rd}, 4 t h$ and $5 t h$ quintile are very similar indicating that there is something like decreasing returns to differentiation, i.e. at some point a further increase in differentiation does not lead to a further increase in performance.

\section{Further Robustness Checks and Extensions}

To check the robustness of our results and to validate the key independent variable we conducted further analyses which are described in the following. In a first step we replicate the baseline regressions for a substantially smaller data set where an organizational unit is the unit of observation. As explained in the above, a unit is identified by a unique combination of year, company, functional area, function, career ladder and hierarchical level. The key independent variable is the average bonus in a unit. We then estimate regressions with unit fixed effects. As the results reported in table A8 in the appendix show, the positive performance effects of higher differentiation levels can again be confirmed.

Furthermore, we did a simple falsification exercise by running (unit-)fixed effects regressions with the coefficient of variation as dependent variable and the lagged logarithm of average bonus payments as independent variable in the reduced unit data set, controlling for average base salary and year effects. The coefficient of the lagged logarithm of bonus payments is insignificant (co-

efficient $0.0306, \mathrm{p}$-value $=0.278$, which supports the idea that differentiation indeed drives performance. 
Finally, we take a closer look at bonus payments as the key dependent variable. As laid out in the above, it is impossible to access a comparable set of financial performance measures on the level of individual units across the different banks. But the financial success is publicly observable for whole banks from balance sheets and profit and loss statements. Hence, we collected financial performance measures (such as the Return on Equity, the Return on Assets or the Net Income) for a subset of the considered banks from the Bankscope data base.

First, we used this data to validate whether the bonus paid out to the employees is indeed a good proxy for the performance contribution as our arguments above build on the assumption that higher bonuses are paid out in areas where there is also a higher performance. For these banks we estimated a fixed effects model with the log average bonus payment per bank as dependent variable and the $\log$ of the different financial performance measures as well as year dummies as independent variables. As table 8 shows these elasticities indicate a substantially strong and statistically significant relationship between firm performance and subsequent average bonus levels. Note that we estimate the effects only from the within-bank variation of performance measures and bonus payments over time. Hence, bonus payments indeed seem to be a suitable proxy for performance, as they are directly affected by changes in corporate financial indicators. And indeed, this relationship should be even stronger when the success of individual units could be considered as the bonus pools in banks typically are directly linked to a unit's financial performance.

In a next step we give a first indication on the association between the average degree of differentiation within a bank and the bank's overall financial performance. ${ }^{22}$ As the number of observations of different banks which publish financial information is small (up to 20 banks each year) we compute the Spearman rank correlation coefficient between a firm's average coefficient

\footnotetext{
${ }^{22}$ Descriptive statistics on the variables used are provided in table A9 in the appendix.
} 


\begin{tabular}{lccc}
\hline \hline & \multicolumn{3}{c}{ Firm panel FE regression } \\
Dependent variable: & \multicolumn{3}{c}{ Ln bonus payments } \\
& ROE & ROA & Net income \\
\hline Ln Performance $t-1$ & $0.1590^{* *}$ & $0.2480^{* * *}$ & $0.1960^{* * *}$ \\
& $(0.0736)$ & $(0.0922)$ & $(0.0736)$ \\
\hline Observations & 109 & 108 & 109 \\
$\mathrm{R}^{2}$ within & 0.24 & 0.27 & 0.27 \\
\hline \hline Additional year dummies included. Standard errors in parentheses \\
$* * * \mathrm{p}<0.01,{ }^{* *} \mathrm{p}<0.05,{ }^{*} \mathrm{p}<0.1$
\end{tabular}

Table 8: Pay-for-performance sensitivity

of variation in bonus payments in the years 2004-2007 and the difference in returns on equity between 2007 and 2004, i.e. the years before the financial crisis. Indeed there is a positive and significant relationship between firm performance and previous differentiation levels (Spearman rank correlation coefficient $0.4576, \mathrm{p}$-value $=0.086, \mathrm{n}=15$ ).

In a last step, we also consider data from the recent financial crisis. A potential conjecture could be that more differentiation is associated with higher bank losses as higher powered incentives may have encouraged excessive risk-taking among employees. We find a slightly negative, but statistically insignificant, relationship between average differentiation levels in the pre-crisis period, i.e. average values of the coefficient of variation from 20042007, and the difference in returns on equity between year 2009 and 2007 (Spearman rank correlation coefficient $-0.1434, \mathrm{p}$-value $=0.570, \mathrm{n}=18$ ) But it is important to note that much more detailed data has to be collected to make a robust statement on the connection between pay differentiation and risk-taking behavior. 


\section{Conclusion}

We have analyzed the performance effects of between-employee differentiation in bonus payments. Economic reasoning suggests that differentiation should increase performance, as it implies higher powered incentives. And we indeed found a highly significant and economically substantial average effect of differentiation on performance. However, a more differentiated picture arises when we look at different subsamples in our data set. The positive effect of differentiation is strongest at higher hierarchical levels. But differentiation may be harmful at the lowest levels.

Our results also shed some light on the quite controversial debate among practitioners on methods to increase differentiation in performance appraisals such as forced distribution systems. As recent surveys show, many firms are still adapting the degree of differentiation among high and low performers on the same job and most firms aim at increasing it. A study by the consultancy Mercer, for instance, finds "companies widening performance differentials for short-term incentive payouts [..]. The highest-performing management level employees are expected to receive average short-term incentive payouts of 36 percent compared to just 8 percent for the lowest performers.". A similar survey by Towers Perrin concluded "In 2010, a full 48\% of companies indicated they will continue with the same differentiation strategies they used in 2009 for their 2010 salary review process, while an additional $40 \%$ will differentiate more than in prior years." 23

Our results indicate that for positions in the middle or at the top of the corporate hierarchy firms should indeed strive to achieve differentiated performance ratings, for instance through the introduction of recommended or even forced rating distributions as this positively affects performance. On the other hand, at lower levels firms should be careful when considering to enforce differentiation. For instance, at those levels, team bonus payments

\footnotetext{
${ }^{23}$ See Mercer 2008/2009 US Compensation Planning Survey and Towers Perrin 2009 Survey on Compensation Strategies.
} 
that treat employees equally may be a useful alternative as they support incentives for cooperation and avoid potentially harmful social comparisons. 


\section{References}

Abeler, J., S. Altmann, S. Kube, and M. Wibral (2010). Gift exchange and workers' fairness concerns: When equality is unfair. Journal of the European Economic Association 8(6), 1299-1324.

Abowd, J. M. and D. S. Kaplan (1999). Executive compensation: Six questions that need answering. Journal of Economic Perspectives 13(4), 145168.

Akerlof, G. A. and J. L. Yellen (1990). The fair wage-effort hypothesis and unemployment. Quarterly Journal of Economics 105(2), 255-283.

Bandiera, O., I. Barankay, and I. Rasul (2007). Incentives for managers and inequality among workers: Evidence from a firm-level experiment. Quarterly Journal of Economics 122(2), 729-773.

Becker, B. E. and M. A. Huselid (1992). The incentive effects of tournament compensation systems. Administrative Science Quarterly 37(2), 336-350.

Berger, J., C. Harbring, and D. Sliwka (2010). Performance appraisals and the impact of forced distribution: An experimental investigation. IZA Discussion Paper No. 5020.

Bloom, M. (1999). The performance effects of pay dispersion on individuals and organizations. Academy of Management Journal 42(1), 25-40.

Bloom, M. and J. G. Michel (2002). The relationships among organizational context, pay dispersion, and among managerial turnover. Academy of Management Journal 45(1), 33-42.

Bol, J. C. (2011). The determinants and performance effects of managers' performance evaluation biases. The Accounting Review (forthcoming). 
Card, D., A. Mas, E. Moretti, and E. Saez (2010). Inequality at work: The effect of peer salaries on job satisfaction. NBER Working Paper No. 16396.

Crutzen, B. S., O. Swank, and B. Visser (2010). Confidence management: On interpersonal comparisons in teams. Tinbergen Institute Discussion Paper.

Depken II, C. A. (2000). Wage disparity and team productivity: evidence from major league baseball. Economics Letters 67(1), 87-92.

Drago, R. and G. T. Garvey (1998). Incentives for helping on the job: Theory and evidence. Journal of Labor Economics 16(1), 1-25.

Engellandt, A. and R. T. Riphahn (2011). Evidence on incentive effects of subjective performance evaluations. Industrial and Labor Relations Review 64 (2), 241-257.

Eriksson, T. (1999). Executive compensation and tournament theory: Empirical tests on danish data. Journal of Labor Economics 17(2), 262-280.

Fehr, E., S. Gächter, and G. Kirchsteiger (1997). Reciprocity as a contract enforcement device - experimental evidence. Econometrica 65(4), 833-860.

Fehr, E., G. Kirchsteiger, and A. Riedl (1993). Does fairness prevent market clearing? an experimental investigation. Quarterly Journal of Economics 108(2), 437-460.

Grund, C. and N. Westergaard-Nielsen (2008). The dispersion of employees' wage increases and firm performance. Industrial and Labor Relations Review 61(4), 485-501.

Halvorsen, R. and R. Palmquist (1980). The interpretation of dummy variables in semilogarithmic equations. American Economic Review 70(3), 474-475. 
Heyman, F. (2005). Pay inequality and firm performance: evidence from matched employer-employee data. Applied Economics 37(11), 1313-1327.

Hossain, T. and J. A. List (2009). The behavioralist visits the factory: Increasing productivity using simple framing manipulations. NBER Working Paper No. 15623.

Jirjahn, U. and K. Kraft (2007). Intra-firm wage dispersion and firm performance - is there a uniform relationship? Kyklos 60(2), 231-253.

Kane, J. S., H. J. Bernardin, P. Villanova, and J. Peyrefitte (1995). Stability of rater leniency: Three studies. Academy of Management Journal 38(4), $1036-1051$.

Knez, M. and D. Simester (2001). Firm-wide incentives and mutual monitoring at continental airlines. Journal of Labor Economics 19(4), 743-772.

Lazear, E. P. (1989). Pay equality and industrial politics. Journal of Political Economy $97(3), 561-580$.

Lazear, E. P. (2000). Performance pay and productivity. American Economic Review 90(5), 1346-1362.

Lazear, E. P. and S. Rosen (1981). Rank-order tournaments as optimum labor contracts. Journal of Political Economy 89(5), 841-864.

Leonard, J. S. (1990). Executive pay and firm performance. Industrial and Labor Relations Review 43(3), 13-S-29-S.

Main, B. G. M., C. A. O'Reilly III, and J. Wade (1993). Top executive pay: Tournament or teamwork? Journal of Labor Economics 11(4), 606-628.

Martins, P. S. (2008). Dispersion in wage premiums and firm performance. Economics Letters 101(1), 63-65. 
Murphy, K. J. (1999). Executive compensation. In O. Ashenfelter and D. Card (Eds.), Handbook of Labor Economics, Volume 3, Amsterdam. North-Holland.

Murphy, K. J. (2001). Performance standards in incentive contracts. Journal of Accounting and Economics 30(3), 245-278.

Murphy, K. R. and J. N. Cleveland (1995). Understanding Performance Appraisal. Thousand Oaks: Sage.

Ockenfels, A., D. Sliwka, and P. Werner (2010). Bonus payments and reference point violations. IZA Discussion Paper No. 4795.

Pfeffer, J. and N. Langton (1993). The effect of wage dispersion on satisfaction, productivity, and working collaboratively: Evidence from college and university faculty. Administrative Science Quarterly 38(3), 382-407.

Pfeffer, J. and R. Sutton (2006). Hard facts, dangerous half-truths, and total nonsense: Profiting from evidence-based management. Harvard Business Press.

Prendergast, C. and R. Topel (1996). Favoritism in organizations. Journal of Political Economy 104(5), 958-978.

Prendergast, C. J. (2002). Uncertainty and incentives. Journal of Labor Economics 20(2), 115-137.

Rynes, S. L., B. Gerhart, and L. Parks (2005). Personnel psychology: Performance evaluation and pay for performance. Annual Review of Psychology $56(1), 571-600$.

Welch, J. (2003). Jack-Straight from the Gut. Warner Books.

Winter-Ebmer, R. and J. Zweimüller (1999). Intra-firm wage dispersion and firm performance. Kyklos 52(4), 555-572. 


\section{Appendix}

\begin{tabular}{ll}
\hline \hline \multicolumn{1}{c}{ Functional Areas and Functions } \\
\hline Retail Banking & Corporate and Private Banking \\
Retail Banking Product Development & Corporate Banking Product Development \\
Retail Sales & Corporate / Institutional Relationship \\
Telebanking Sales & Client Relationship Management \\
Financial Advice & Portfolio Management \\
& \\
Investment Banking/Asset Management & Corporate Production \\
Treasury and Capital Markets & Human Resources \\
Asset Allocation & Legal / Economics \\
Credit Syndication & Risk Management \\
Money Markets & Sales \& Marketing \\
Hedge Funds & Finance / Accounting \\
Asset Management Product Development & Project Management \\
Money Transfers & \\
Fund Management & Corporate Services \\
Structured Finance & IT Administration / Support \\
Corporate Finance & IT Architecture \\
Commodity Trading & Customer Service \\
Fixed Income & Asset Management Support \\
Equity & Foreign Operations \\
\hline \hline
\end{tabular}

Table A1: Examples of functional areas and functions 


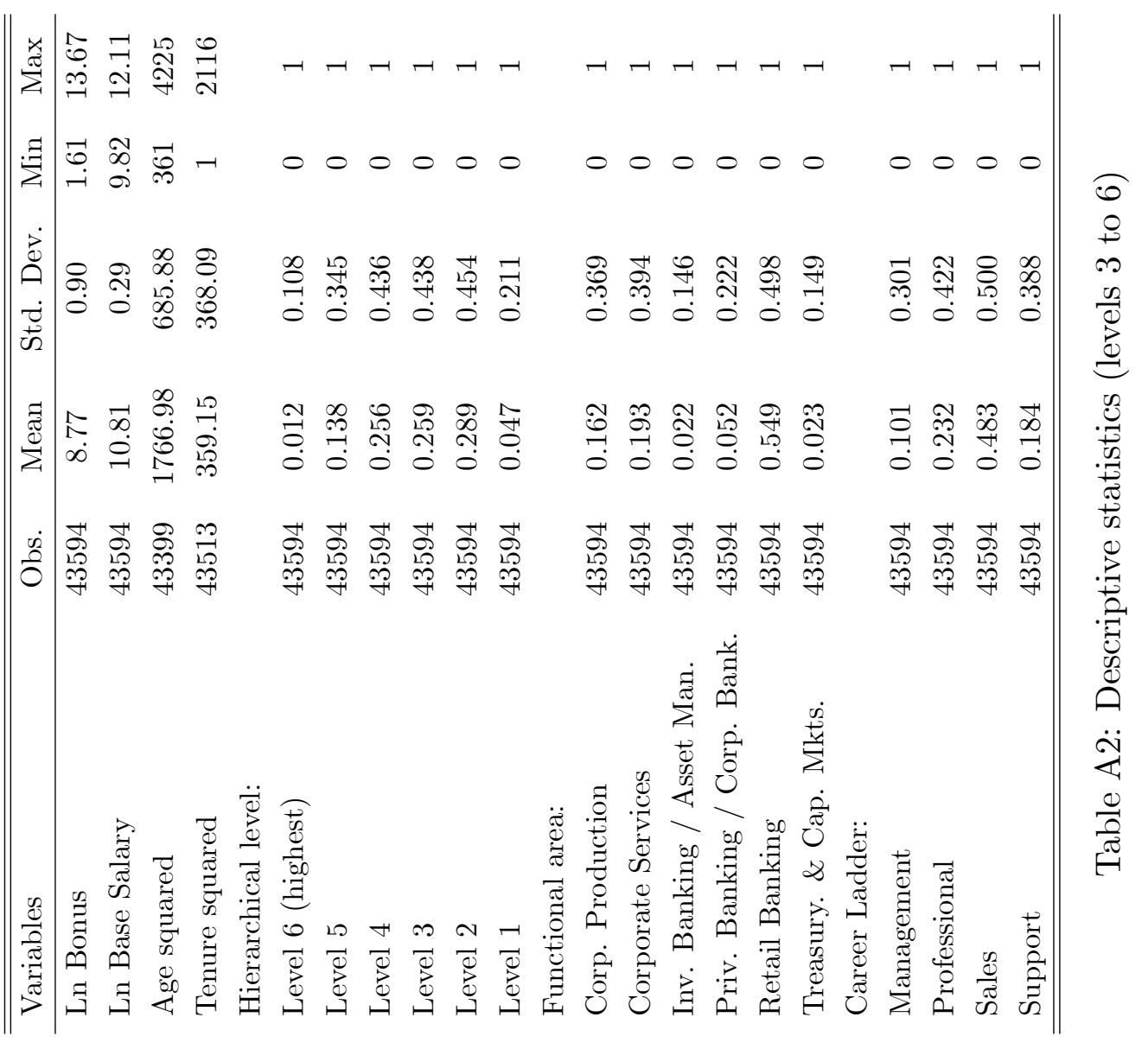




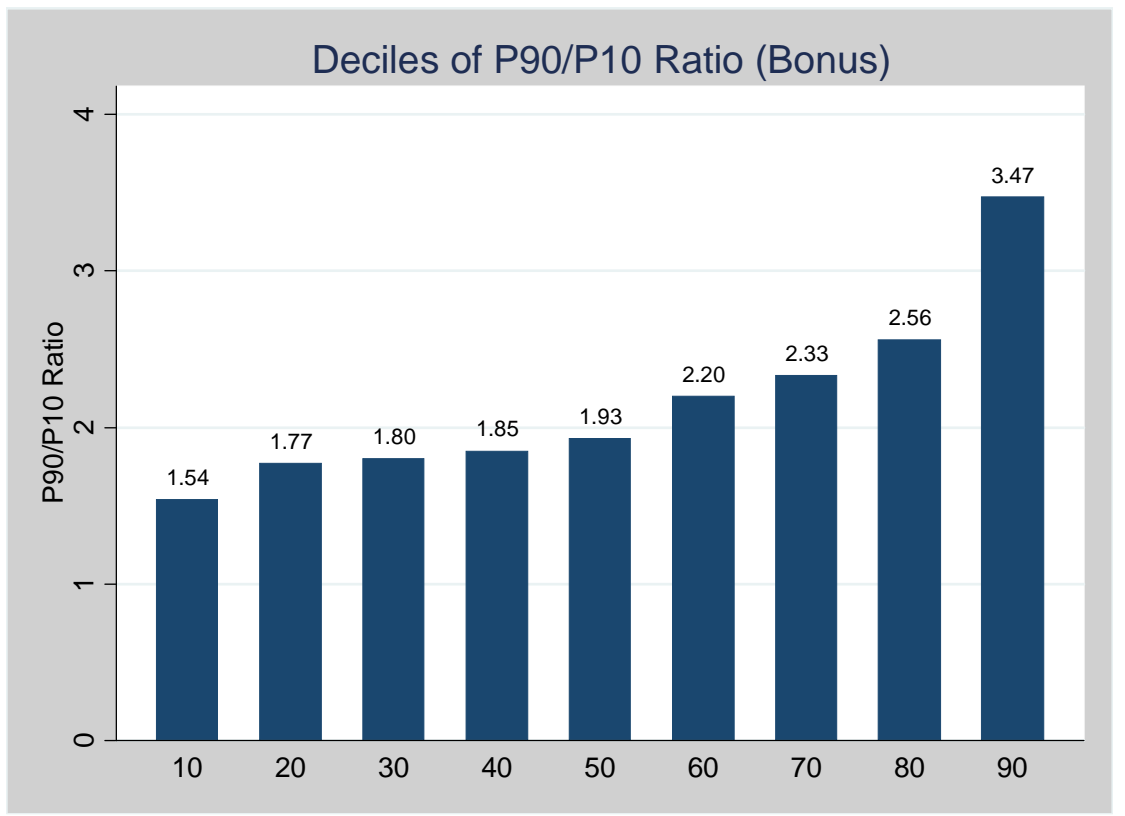

Figure 3: Deciles of P90/P10 ratio for bonus payments 


\begin{tabular}{l|l|l|l|l|l|l}
\hline \hline Level & \multicolumn{3}{|c|}{ Median coef. of variation } & \multicolumn{3}{c}{ Median P90/P10 ratio } \\
& 2005 & 2006 & 2007 & 2005 & 2006 & 2007 \\
\hline 6 & 0.33 & 0.29 & 0.27 & 2.24 & 2.12 & 2.40 \\
5 & 0.36 & 0.34 & 0.34 & 2.29 & 2.35 & 2.32 \\
4 & 0.35 & 0.30 & 0.33 & 2.33 & 2.17 & 2.27 \\
3 & 0.21 & 0.22 & 0.23 & 1.76 & 1.80 & 1.85 \\
2 & 0.23 & 0.25 & 0.26 & 1.77 & 1.82 & 1.91 \\
1 & 0.22 & 0.25 & 0.20 & 1.77 & 1.93 & 1.47 \\
\hline Total & 0.27 & 0.27 & 0.27 & 1.98 & 1.90 & 1.91 \\
\hline \hline
\end{tabular}

Table A3: Differentiation over year and hierarchical level

\begin{tabular}{l|c|c|c|c|c|c}
\hline \hline Funct. area & \multicolumn{3}{|c|}{ Median coef. of variation } & \multicolumn{4}{|c}{ Median P90/P10 ratio } \\
& 2005 & 2006 & 2007 & 2005 & 2006 & 2007 \\
\hline $\mathrm{CP}$ & 0.38 & 0.40 & 0.33 & 2.48 & 2.57 & 2.30 \\
$\mathrm{CS}$ & 0.30 & 0.32 & 0.28 & 2.21 & 2.07 & 2.16 \\
$\mathrm{IB} / \mathrm{AM} / \mathrm{TCM}$ & 0.50 & 0.52 & 0.54 & 3.33 & 3.34 & 3.73 \\
$\mathrm{~PB} / \mathrm{CB}$ & 0.33 & 0.33 & 0.32 & 2.24 & 2.20 & 2.22 \\
$\mathrm{RB}$ & 0.23 & 0.25 & 0.26 & 1.77 & 1.82 & 1.91 \\
\hline \hline
\end{tabular}

Table A4: Differentiation over year and functional area 


\begin{tabular}{|c|c|c|c|c|c|c|}
\hline \multirow[t]{2}{*}{ Dependent variable: } & \multicolumn{6}{|c|}{ Logarithm of bonus payments (Balanced panel 2005-2007) } \\
\hline & \multicolumn{2}{|c|}{ Level $5+6$} & \multicolumn{2}{|c|}{ Level $3+4$} & \multicolumn{2}{|c|}{ Level $1+2$} \\
\hline CV Bonus $_{t-1}$ & $\begin{array}{c}0.9236^{* * *} \\
(0.1327)\end{array}$ & & $\begin{array}{c}0.6588^{* * *} \\
(0.2006)\end{array}$ & & $\begin{array}{r}-1.0701^{*} \\
(0.4003\end{array}$ & \\
\hline $2^{\text {nd }}$ Quintile $_{t-1}$ & & $\begin{array}{c}0.1903 \\
(0.1338)\end{array}$ & & $\begin{array}{c}0.0559 \\
(0.1048)\end{array}$ & & $\begin{array}{c}0.1351 \\
(0.1513)\end{array}$ \\
\hline $3^{r d}$ Quintile $_{t-1}$ & & $\begin{array}{c}0.1921 \\
(0.1628)\end{array}$ & & $\begin{array}{c}0.0636 \\
(0.1035)\end{array}$ & & $\begin{array}{c}0.1541 \\
(0.1357)\end{array}$ \\
\hline $4^{t h}$ Quintile $_{t-1}$ & & $\begin{array}{c}0.2429 \\
(0.1748)\end{array}$ & & $\begin{array}{c}0.2227^{* *} \\
(0.0924)\end{array}$ & & $\begin{array}{c}0.1757 \\
(0.2864)\end{array}$ \\
\hline $5^{t h}$ Quintile $_{t-1}$ & & $\begin{array}{c}0.3094 \\
(0.2233) \\
\end{array}$ & & $\begin{array}{c}0.3241^{* * *} \\
(0.1028)\end{array}$ & & $\begin{array}{l}-0.0292 \\
(0.2845) \\
\end{array}$ \\
\hline Observations & 3540 & 3540 & 13155 & 13155 & 8892 & 8892 \\
\hline $\mathrm{R}^{2}$ within & 0.25 & 0.12 & 0.17 & 0.12 & 0.10 & 0.03 \\
\hline
\end{tabular}

Age squared, base salary and year dummies included. Robust standard errors clustered for cells in parentheses. ${ }^{* * *} \mathrm{p}<0.01,{ }^{* *} \mathrm{p}<0.05,{ }^{*} \mathrm{p}<0.1$

Table A5: Fixed effects regression results for hierarchical levels (coefficient of variation) 


\begin{tabular}{|c|c|c|c|c|c|c|}
\hline \multirow[t]{2}{*}{ Dependent variable: } & \multicolumn{6}{|c|}{ Logarithm of bonus payments (Balanced panel 2005-2007) } \\
\hline & \multicolumn{2}{|c|}{ Level $5+6$} & \multicolumn{2}{|c|}{ Level $3+4$} & \multicolumn{2}{|c|}{ Level $1+2$} \\
\hline \multirow[t]{2}{*}{ P90/P10 Bonus $t-1$} & $0.0638^{* * *}$ & & $0.0183^{* *}$ & & -0.0188 & \\
\hline & $(0.0124)$ & & $(0.0086)$ & & $(0.0220$ & \\
\hline \multirow[t]{2}{*}{$2^{n d}$ Quintile $_{t-1}$} & & $-0.1904^{* * *}$ & & $-0.1644^{* * *}$ & & $0.0822^{*}$ \\
\hline & & $(0.0534)$ & & $(0.0418)$ & & $(0.0454)$ \\
\hline \multirow[t]{2}{*}{$3^{r d}$ Quintile $_{t-1}$} & & 0.1929 & & 0.0838 & & $0.3084^{* * *}$ \\
\hline & & $(0.1666)$ & & $(0.0652)$ & & $(0.1057)$ \\
\hline \multirow[t]{2}{*}{$4^{t h}$ Quintile $_{t-1}$} & & 0.2513 & & $0.2861^{* * *}$ & & -0.1373 \\
\hline & & $(0.1560)$ & & $(0.0697)$ & & $(0.1968)$ \\
\hline \multirow[t]{2}{*}{$5^{\text {th }}$ Quintile $_{t-1}$} & & $0.3139 *$ & & $0.2574^{* * *}$ & & 0.0117 \\
\hline & & $(0.1692)$ & & $(0.0726)$ & & $(0.1242)$ \\
\hline Observations & 3540 & 3540 & 13155 & 13155 & 8892 & 8892 \\
\hline $\mathrm{R}^{2}$ within & 0.27 & 0.12 & 0.11 & 0.14 & 0.01 & 0.10 \\
\hline
\end{tabular}

Age squared, base salary and year dummies included. Robust standard errors clustered for cells in parentheses. ${ }^{* * *} \mathrm{p}<0.01,{ }^{* *} \mathrm{p}<0.05,{ }^{*} \mathrm{p}<0.1$

Table A6: Fixed effects regression results for hierarchical levels (P90/P10 ratio) 


\begin{tabular}{|c|c|c|c|c|}
\hline \multirow[t]{2}{*}{ Dependent variable: } & \multicolumn{4}{|c|}{$\begin{array}{c}\text { Logarithm of bonus payments (Balanced panel 2005-2007) } \\
\text { Coefficient of variation }\end{array}$} \\
\hline & \multicolumn{2}{|c|}{ Management } & \multicolumn{2}{|r|}{ Professional } \\
\hline Differentiation Bonus $_{t-1}$ & $\begin{array}{c}2.4454^{* * *} \\
(0.2070)\end{array}$ & & $\begin{array}{c}0.4850^{* * *} \\
(0.0876)\end{array}$ & \\
\hline $2^{n d}$ Quintile $_{t-1}$ & & $\begin{array}{c}0.5934^{* *} \\
(0.2412)\end{array}$ & & $\begin{array}{c}0.1377 \\
(0.1216)\end{array}$ \\
\hline $3^{r d}$ Quintile $_{t-1}$ & & $\begin{array}{l}0.5343^{*} \\
(0.2974)\end{array}$ & & $\begin{array}{c}0.2704^{* * *} \\
(0.1039)\end{array}$ \\
\hline $4^{t h}$ Quintile $_{t-1}$ & & $\begin{array}{c}0.6636^{* *} \\
(0.3080)\end{array}$ & & $\begin{array}{c}0.2515^{* * *} \\
(0.0890)\end{array}$ \\
\hline $5^{\text {th }}$ Quintile $_{t-1}$ & & $\begin{array}{c}1.9115^{* * *} \\
(0.3722)\end{array}$ & & $\begin{array}{c}0.2462^{* * *} \\
(0.0792) \\
\end{array}$ \\
\hline Observations & 2263 & 2263 & 5704 & 5704 \\
\hline $\mathrm{R}^{2}$ within & 0.56 & 0.36 & 0.19 & 0.15 \\
\hline
\end{tabular}

Age squared, base salary and year dummies included. Robust standard errors clustered for cells in parentheses. $* * * \mathrm{p}<0.01,{ }^{* *} \mathrm{p}<0.05,{ }^{*} \mathrm{p}<0.1$

Table A7: Differentiation within career ladders (coefficient of variation) 


\begin{tabular}{|c|c|c|}
\hline Dependent variable: & \multicolumn{2}{|c|}{$\begin{array}{c}\text { Log. of average bonus payments } \\
\text { Unit-level panel 2005-2007 (weighted) }\end{array}$} \\
\hline CV Bonus ${ }_{t-1}$ & $\begin{array}{l}0.1453^{*} \\
(0.0802)\end{array}$ & \\
\hline $2^{n d}$ Quintile $_{t-1}$ & & $\begin{array}{c}0.0489 \\
(0.0929)\end{array}$ \\
\hline $3^{r d}$ Quintile $_{t-1}$ & & $\begin{array}{c}0.1366 \\
(0.0921)\end{array}$ \\
\hline $4^{t h}$ Quintile $_{t-1}$ & & $\begin{array}{l}0.2393^{* *} \\
(0.0965)\end{array}$ \\
\hline $5^{t h}$ Quintile $_{t-1}$ & & $\begin{array}{l}0.1770^{*} \\
(0.1065)\end{array}$ \\
\hline Observations & 850 & 850 \\
\hline $\mathrm{R}^{2}$ within & 0.08 & 0.09 \\
\hline
\end{tabular}

Additional control variables include average base salary and year dummies. Weighting variable represents cell size.

$* * * \mathrm{p}<0.01,{ }^{*} * \mathrm{p}<0.05,{ }^{*} \mathrm{p}<0.1$. Robust standard errors in parentheses.

Table A8: Fixed effects regressions with collapsed data set (robustness check)

\begin{tabular}{lccccc}
\hline \hline Variables & Obs. & Mean & Std. Dev. & Min & Max \\
\hline Difference ROE 2004-2007 & 29 & 11.364 & 24.899 & -3.04 & 125.07 \\
Difference ROE 2007-2009 & 34 & -11.981 & 26.288 & -141.36 & 14.57 \\
Average coefficient of variation 2004-2007 & 20 & 1.848 & 0.696 & 0.589 & 3.253 \\
\hline \hline
\end{tabular}

Table A9: Descriptive statistics (firm panel) 